\title{
Are insecure jobs as bad for mental health and occupational commitment as unemployment? Equal threat or downward spiral
}

\author{
Kathleen Otto ${ }^{1 *}$ and Claudia Dalbert ${ }^{2}$ \\ ${ }^{1}$ University of Leipzig, Germany \\ ${ }^{2}$ Martin Luther University of Halle-Wittenberg, Germany
}

\begin{abstract}
We investigated the significance of unemployment and job insecurity for mental health (self-esteem; life satisfaction) and occupational commitment (occupational self-efficacy; affective occupational commitment) comparing the "equal threat" assumption with the "downward spiral" assumption. Whereas the equal threat model suggests that unemployment and (perceived) insecure employment are similarly threatening phenomena, the downward spiral model assumes that there might be a spectrum of employment insecurity, ranging from secure employment to long-term unemployment, that is associated with decreasing mental health and occupational commitment. Controlling for socio-demographic background variables and personality traits, results of ANCOVAs, in which we distinguished between workers who were (more or less) securely employed and those who were either insecurely employed or short- or long-term unemployed revealed that the insecurely employed workers were no better off than those who were (short-term) unemployed - in line with the equal threat hypothesis. Only for occupational self-efficacy did we find some support for the downward spiral model.
\end{abstract}

Key words: unemployment, job security, mental health, occupational commitment, occupational self-efficacy

\section{So negotova delovna mesta enakovredno slaba za duševno zdravje in poklicno pripadnost kot brezposelnost? Enaka grožnja ali spirala navzdol}

\author{
Kathleen Otto ${ }^{1}$ in Claudia Dalbert ${ }^{2}$ \\ ${ }^{1}$ Univerza v Leipzigu, Nemčija \\ ${ }^{2}$ Univerza Martina Luthra v Halle-Wittenbergu, Nemčija
}

\begin{abstract}
Povzetek: V pričujoči študiji smo proučevali pomembnost brezposelnosti in negotovosti delovnega mesta za duševno zdravje (samospoštovanje, življenjsko zadovoljstvo) in poklicno pripadnost (poklicna samoučinkovitost, afektivna organizacijska pripadnost), pri čemer smo primerjali domnevo enakovrednih groženj z domnevo spirale navzdol. Medtem ko prva domneva predvideva, da sta brezposelnost in negotovost delovnih mest podobno ogrožajoča fenomena, slednja predvideva celoten spekter negotovosti delovnih mest od varne zaposlitve do dolgotrajne brezposelnosti, ki je v tej smeri povezan z vse slabšim duševnih zdravjem in z nižjo poklicno pripadnostjo. Ob vključitvi kontrolnih demografskih in osebnostnih spremenljivk, so ANCOVA analize, v katerih smo ločili med skupinami (bolj ali manj) varno zaposlenih uslužbencev, tistih z negotovimi delovnimi mesti in tudi kratko- ter dolgotrajno brezposelnimi, pokazale, da uslužbenci z negotovimi delovnimi mesti niso bistveno na boljšem kot kratkotrajno brezposelni. Navedeno je v skladu z domnevo enakovrednih groženj. Pri poklicni samoučinkovitosti naši rezultati delno podpirajo tudi model spirale navzdol.
\end{abstract}

Ključne besede: nezaposlenost, varnost zaposlitve, duševno zdravje, zaposlitvena predanost, poklicna samoučinkovitost

\footnotetext{
"Naslov/Address: Kathleen Otto now at: Philipps University of Marburg, Faculty of Psychology, Work and Organizational Psychology, Gutenbergstr. 18, D-35032 Marburg, Germany; Phone: +49 6421/28-23781; Fax: +49 6421/28-24281; e-mail: kathleen. otto@staff.uni-marburg.de
} 
Forty-eight per cent of EU citizens consider unemployment to be the main concern in their country (Eurobarometer, 2012). The financial crises in 2007 in particular led to high unemployment figures worldwide, the likes of which were last reported during the time of the Great Depression (i.e., the 1930's). Accordingly, high unemployment, temporary layoffs, involuntary part-time (under-) employment, hiring on temporary employment contracts and working in the field of casual labor, have all become marks of current vocational development. These facts suggest that a growing number in the workforce might suffer (or believe themselves to be suffering) from the risk of losing their jobs (Sverke, Hellgren \& Näswall, 2002). Interestingly, Schwarz (2012) found that a $1 \%$ increase in the regional unemployment rate corresponds to a $0.6 \%$ increase in perceived job insecurity ratings.

In the present article, we focus on unemployment, as well as job insecurity, and explore their respective relationships with indicators of mental health (selfesteem, life satisfaction) and occupational commitment (occupational self-efficacy, affective occupational commitment). We intend to go beyond former research by comparing unemployed individuals with those who are more or less (in)securely employed. In doing so we investigate, on the one hand, the "equal threat" hypothesiswhich states that unemployment and insecure employment are equally distressing to the individual - while on the other hand, we explore the opposing "downward spiral" hypothesis, that proposes an "employment insecurity continuum", ranging from secure employment to longterm unemployment that is associated with decreasing mental health and occupational commitment. In sum, we contribute to the literature by attempting to shed further light on the question as to whether or not job insecurity is less threatening than unemployment.

\section{Unemployment, Job Insecurity and Mental Health}

Unemployment research to date has indicated that most people highly value (paid) work (e.g., Jahoda, 1997; Paul, Geithner, \& Moser, 2009) because it serves various vital functions, such as structuring the daily routine of employees, strengthening their self-confidence, and offering them social rewards (i.e., co-operation, social contact, appreciation). Furthermore, research indicates that unemployment itself is commonly associated with stigmas (Kulik, 2001), such as laziness, apathy, or is even seen as a 'contagious disease' (Letkemann, 2002). Given this research, it is no surprise to find that many studies report unemployment to be an important stressor that leads to states of decreased mental health (for reviews, see Mohr \& Otto, 2011; Paul \& Moser, 2009).

The hypothesis that the negative consequences of unemployment on health are more severe the longer the unemployed individuals are out of work seems logical. In most countries, being unemployed for a longer period of time is associated with reduced financial resources and studies have shown a correlation between reduced financial funds and mental impairment (e.g., Elovainio, Kivimäki, Kortteinen, \& Tuomikoski 2001). Meta-analytic data indicate that the long-term unemployed (i.e., those who have been without a paid job for one year or more) are at higher risk of negative consequences for mental health than the short-term unemployed (Paul \& Moser, 2006). In addition, the long-term unemployed are frequently victims of social exclusion (Kieselbach, 2003). Analyzing national statistics, Grobe (2006) found that the death rate is 3.9 times higher among the long-term unemployed than among the continuously employed-a result that does not apply to those unemployed for only a short time. In sum, it can be derived that long-term unemployment is worse for mental health than short-term unemployment.

Changes in the labor market have not only made it more difficult for unemployed people to find new jobs but have also caused currently employed people to feel increasingly threatened by the risk of losing their jobs (Sverke et al., 2002). In general, job insecurity is defined as the "overall concern about the future existence of the job" (Rosenblatt \& Ruvio, 1996, p. 587). Comparable to unemployment, job insecurity can be seen as a psychological stressor that results in poor mental health (for a review, see De Witte, 1999) as indicated, for example, by strain, depression, and lower self-esteem (Kinnunen, Feldt, \& Mauno, 2003; Mohr, 2000; Otto, Hoffmann-Biencourt, \& Mohr, 2011).

A study by Broom et al. (2006) indicates that employees working in poor quality jobs with three or more psychosocial stressors, such as job insecurity, concerns about one's own marketability, or job strain, report health that is no better than that of the unemployed. Similarly, findings from Butterworth et al. (2011) suggest that the mental health benefits of having a job by comparison with being unemployed depend on the job's psychosocial quality in terms of levels of control, demands and complexity, job insecurity, and unfair pay.

In the present research we aim at exploring if unemployment and insecure employment are indeed equally threatening to the individual (equal threat model) or if there is an employment insecurity continuum (downward spiral model) ranging from secure employment to long-term unemployment by considering two positive dimensions of mental health, namely self-esteem and life satisfaction. Even though both concepts share common variance, they were found to be distinguishable from each other (see Lucas, Diener, \& Suh, 1996). In particular, selfesteem belongs to the core self-evaluations of a person, reflects the appraisal of one's self-worth (see Judge, 2009), and addresses the extent to which a person believes him- or herself to be successful, capable, significant and worthy ( Rosenberg, Schoenbach, Schooler, \& Rosenberg, 1995). This concept was chosen because in prior studies it emerged as sensitive to interruptions in one's work history (Keddy, Cable, Quinn, \& Melanson, 1993), experiences of job insecurity (Kinnunen et al., 2003) and unemployment (Paul \& Moser, 2009). In contrast to self-esteem, life satisfaction is part of subjective well-being and depicts the global cognitive evaluation of one's life (see, Clark, 
Diener, Georgellis, \& Lucas, 2008). With respect to unemployment, life satisfaction has been a frequently studied outcome with former research indicating that unemployed as compared to employed individuals possess overall lower life satisfaction (McKee-Ryan, Song, Wanberg, \& Kinicki, 2005), and that unemployment decreases and actually alters the set point for life satisfaction (Lucas, Clark, Georgellis, \& Diener 2004).

\section{Unemployment, Job insecurity, and Occupational Commitment}

While there are studies confirming the negative effects of unemployment and job insecurity on various mental health dimensions (for reviews, see De Witte, 1999; Paul \& Moser, 2009), there is no empirical research on the effects of these stressors on occupational commitment. So far, what is known is that employment biography disruptions accumulate (Mauno, Feldt, Tolvanen, Hyvönen \& Kinnunen, 2011). Anyone who has ever been unemployed previously has a higher risk of becoming unemployed again (Bender, Konietzka, \& Sopp, 2000). In addition to the higher risk of future unemployment, unemployed individuals are also often victims of prejudice. Experimental research indicates, for example, that employers are reluctant to employ formerly unemployed individuals as they are assumed to perform worse than their employed counterparts (e.g., OberholzerGee, 2008). Against this background, we argue that it is important for an individual's future biography (1) to believe they are capable in dealing with occupational demands, and (2) to stay attached to work, or more specifically, to one's occupation. Hence, we explored not only mental health dimensions in this study but also occupational commitment.

We define occupational commitment as consisting of two dimensions, a cognitive dimension and an affective dimension. The cognitive dimension covers trust in one's own occupational abilities (=high occupational self-efficacy), and the affective one, the identification with one's own occupation (=high affective occupational commitment). Overall, self-efficacy beliefs reflect people's appraisals of their ability to execute a specific behavior (Bandura, 1997). In particular, occupational self-efficacy beliefs reflect a person's cognitive evaluation of his or her ability to deal with problems and hindrances that may occur on the job (see Schyns \& von Collani, 2002). Affective occupational commitment is an affective dimension, defined as the "psychological link between a person and his or her occupation that is based on an affective reaction to that occupation" (Lee, Carswell, \& Allen, 2000, p. 800). Feeling confident that one's current job is the right one and that one can meet its occupational demands, or, in other words, not having to worry about feeling incompetent in the workplace, will promote one's employability. Occupational commitment can therefore be seen as the operative factor for determining an employee's future career prospects.
The question remains as to whether or not the concepts of occupational self-efficacy and affective occupational commitment are also meaningful for unemployed individuals. There are three reasons for believing this to be the case: First, an occupation "is made up of a constellation of requisite skills, knowledge, and duties that differentiate it from other occupations and, typically, is transferable across settings [...] implying [...] that membership in an occupation is not inherently linked to a particular employing organization" (Lee et al., 2000, p. 800 ; italics added by the authors). This definition would suggest that unemployed people can feel attached to their occupation, as well. Second, unemployment strongly impacts employability as unemployed individuals have fewer opportunities to use their once-learned skills than employed individuals do (Jackson, 1999). Obviously, the disuse of skills becomes more dramatic the longer the time of unemployment. As self-efficacy expectations can best be fostered by successful management of occupational demands (cf. Bandura, 1997), the disuse of skills might diminish the occupational self-efficacy of the unemployed. Third and most importantly, we believe that occupational commitment is a decisive factor for increasing the chances of the unemployed to become reemployed. In line with this argument, Rigotti, Schyns, and Mohr (2008) recommend, for example, the application of the concept of occupational self-efficacy when evaluating the effects of an intervention for unemployed individuals.

\section{The Present Research: Aims and Hypotheses}

While there has been only little research aimed at comparing the mental health of employed and unemployed individuals, the studies to date derive two contradictory hypotheses, which we label the equal threat hypothesis and the downward spiral hypothesis:

One branch of research suggests that unemployment and job insecurity might be regarded as similarly threatening (equal threat model). According to Conservation of Resources (COR) theory (Hobfoll, 1989), individuals strive to obtain, retain, foster, and protect those things in life they centrally value - such as a secure and satisfying job. In order to avoid stress, individuals strive to gain resources, and then try to conserve and guard these resources (Hobfoll \& Shirom, 2001). Resources include objects (e.g., cars), conditions (e.g., supportive work relationships), personal characteristics (e.g., key skills), and energy (e.g., knowledge). Stress accrues if (a) individuals are threatened by a loss of resources, (b) if they actually lose resources, or (c) if the gaining of resources has failed (Hobfoll, 1989). Applying COR theory to the particular field of this study, if a person (b) either lost his or her job in the past-as is the case for unemployed individuals-or (a) feels a threat of losing it in the future-as is the case for those with high perceived job insecurity-he or she reacts with strain. Interestingly, various scholars have already emphasized that the distress associated with anticipation 
of redundancy (threatened by loss of a resource) is comparable to the distress associated with the experience of unemployment (actual loss of a resource) itself (e.g., Broom et al., 2006; Butterworth et al., 2011; De Witte, 1999; Dekker \& Schaufeli, 1995). If we follow this line of thinking and transfer the assumption that unemployment and job insecurity are equally threatening to the field of occupational commitment, we can assume the following:

Hypothesis 1: Based on the equal threat model, insecurely employed individuals and unemployed individuals will report the same levels of (H1a) selfesteem, (H1b) life satisfaction, (H1c) occupational selfefficacy, and (H1d) affective occupational commitment.

Yet, not all studies are in line with the postulation of the equal threat model. Some studies only found employment status to be associated with differences in mental health in that employed respondents reported lower levels of stress or higher life satisfaction than did unemployed respondents (e.g., Clark et al., 2008; Mantler, Matejicek, Matheson, \& Anisman, 2005). It is also worth noting that previous research has quite often also not differentiated between short-term and long-term unemployment (e.g., Mantler et al., 2005), or has only considered short-term unemployed as comparison group for employed individuals (De Witte, 1999). This raises the question of what happens if people stay unemployed for a longer period of time, and as proposed by COR theory, the gaining of resources i.e., getting a new secure and satisfying job, fails? Against this background it still remains to be explored whether long-term unemployment is the same or more severe than insecure employment or short-term employment.

Gzrywacz and Dooley (2003) compared different employment statuses and found evidence for an employment continuum varying from optimal employment to unemployment. Note, that the authors again neither looked into differences between short-term and long-term unemployed nor did they include job insecurity in their conceptualization of an employment continuum. In her latent deprivation model, Jahoda (1997; see also Paul et al., 2009) postulates that besides having the manifest function of earning a living, in accordance with basic human needs work serves five latent functions. These functions cannot be fulfilled if people are unemployed. Moreover, it can be assumed that the longer the deprivation lasts the more severe its consequences. Therefore, the threat of such deprivation caused by high job insecurity perceptions might also be important.

Referring to meta-analytic findings regarding the necessity to separate the short-term from the long-term unemployed (Paul \& Moser, 2006) and the need to differentiate between employees with different levels of job insecurity (Sverke et al., 2002), we argue that (job) insecurity can also be seen as process ranging from secure employment to long-term unemployment (downward spiral model). We label this continuum "employment insecurity" to differentiate it from the term job insecurity. Following this line of reasoning, we propose that the perception of employment insecurity might range across five groups, starting with secure employment (=low job insecurity) to moderately secure employment (=medium level of job insecurity), to insecure employment (=high job insecurity), to short-term and finally long-term unemployment. As a person moves down a stage of the employment insecurity continuum, the negative consequences of latent deprivation may rise. In our study we therefore classified employed individuals as well as unemployed individuals along the employment insecurity continuum to test the following hypothesis:

Hypothesis 2: Based on the downward spiral model, the higher the employment insecurity, the lower (H2a) selfesteem, (H2b) life satisfaction, (H2c) occupational selfefficacy, and (H2d) affective occupational commitment. (Note, in contrast to the first hypothesis, differences between the insecurely and short-/long-term unemployed would also be expected).

\section{Method}

\section{Sample}

The sample is part of a broader study on mobility readiness which was conducted in Germany (see Otto \& Dalbert, 2012; Otto, Dette-Hagenmeyer, \& Dalbert, 2010), in particular in the two federal states SaxonyAnhalt and Lower Saxony. For the employed sample we approached organizations in various sectors to achieve generalizability across sectors. Of the ten organizations approached, four agreed to take part in the study. In addition, high school educators were recruited through personal contacts. Some 350 questionnaires were distributed and the response rate was $67.7 \%$. Participants were employed in the service industry (e.g., bank staff; $43.3 \%$ ), the automobile manufacturing industry (23.7\%), the healthcare industry (18.7\%), and education (i.e., high school educators; $14.2 \%$ ). Questionnaires were distributed by the organizations' human resources staff or, in the case of high school educators, by selected colleagues.

The majority of the unemployed individuals were recruited from educational institutions running retraining programs for the unemployed in commercial and IT occupations (e.g., management assistants). Of the six educational institutions that came from the same regions as the employed participants approached, three agreed to participate in the study. In addition, 30\% were recruited through private contacts to ensure that not all respondents were attending retraining programs. Questionnaires were handed out to the participants during their classes.

Overall, the sample comprised $N=334$ unemployed $(n=97)$ and employed $(n=237)$ individuals. The participants' ages varied between 19 and 65 years $(M=35.39 ; S D=11.40)$. One fifth $(20 \%)$ had a university degree; sixty percent of the subjects were females; and $65.9 \%$ lived together with a partner. Of those living with a partner, $18.6 \%$ had an unemployed partner. Regarding their financial situation, $17.1 \%$ of the sample received a personal monthly income of less than 500 EUR, 35.8\% 
between 500 and 1,000 EUR, 31.9\% between 1,000 and 2,000 EUR; the remaining $15.2 \%$ received more than 2,000 EUR.

\section{Instruments}

We first asked the unemployed about their length of unemployment in months, which ranged from one to 144 months $(M=16.79 ; S D=23.37)$. The employed subjects were questioned about their perceived job insecurity, assessed with the item "The risk of losing my job is high" taken from the Job Descriptive Questionnaire (Neuberger \& Allerbeck, 1978). Unless otherwise specified, this and all other items were rated on six-point scales ranging from 1 (=strongly disagree) to 6 (=strongly agree). The average job insecurity rating was below the theoretical scale mean $(M=2.53 ; S D=1.34)$.

Dependent variables. As mental health dimensions, we measured self-esteem with the particular subscale of the Frankfurt Self-Concept Scales (Deusinger, 1986; 10 items; $\alpha=.87$; e.g., "In general, I am satisfied with myself") and life satisfaction with the General Life Satisfaction scale describing satisfaction with one's present and past life and with one's future perspectives (Dalbert, 1992; 7 items; $\alpha=.85$; e.g., "I am satisfied with my life"). Both scales were formerly successfully applied in employed and unemployed samples (e.g., Dzuka \& Dalbert, 2002).

Occupational commitment was reflected by occupational self-efficacy (Schyns \& von Collani, 2002; 19 items; $\alpha=.87$; e.g., "My past experiences in my job have prepared me well for my occupational future"). Several previous studies have found the selected measure to be valid and reliable (e.g., Rigotti et al., 2008). In addition, affective occupational commitment was assessed using a scale comparable to that of Meyer, Allen, and Smith (1993) by averaging 3 items: "I really have an interesting occupation", "My job is absolutely my dream job", "I would change my occupation if I could" (reversed coded; $\alpha=.86$ ).

Descriptive statistics and reliability analyses presented separately for the employed and unemployed samples can be found in Table 1.

Control variables. Given the continuing debate in organizational research about the adequate use of control variables (e.g., Spector \& Brannick, 2011), authors are encouraged to provide explanations for their selection of controls. Previous studies have shown that global personality traits influence both mental health and workrelated cognitions (Soldz \& Vaillant, 1999). This general assumption has been supported with respect to the mental health of unemployed individuals, where neuroticism was found to be particularly important (Creed, Muller, \& Machin, 2001). Research has provided evidence to support the assertion that personality traits also play a role in the relationship between job insecurity and mental health (Mark \& Mueller, 2000). The results from meta-analytic data suggest that in particular, neuroticism, extraversion, and conscientiousness predict mental health (DeNeve \& Cooper, 1998). We therefore additionally assessed these three personality traits in our study and measured them using a German short form of the NEO-FFI (Costa \& McCrae, 1989; German version: Trautwein et al., 2000). This short form captured neuroticism $(\alpha=.80$; e.g., "I often feel tense and jittery"), extraversion ( $\alpha=.68$; e.g., "I like to have a lot of people around me"), and conscientiousness $(\alpha=.66$; e.g., "I have a clear set of goals and work toward them in an orderly fashion") with six items each.

\section{Categorizing employment insecurity}

In order to differentiate between the securely employed and the insecurely employed, we categorized the employed people according to their job insecurity ratings: Overall, $n=53$ employees were in the bottom quartile of the distribution, reporting no job insecurity at all (=securely employed; $M=1.00$ ), whereas $n=47$ employees were in the top quartile of the distribution, reporting moderate to strong job insecurity (=insecurely employed; $M \geq 4.00$ ). The remaining employed subjects were classified as more or less securely employed $(M=2.00-3.00 ; n=137)$. Next, the unemployed subjects were grouped into two categories according to length of unemployment: The first group consisted of people who had been unemployed for less than 12 months (=short-term unemployed; $n=56$ ). The second group included people whose unemployment had lasted longer than 12 months (=long-term unemployed; $n=41$ ). In sum, employment insecurity varied between 0 "securely employed or extremely low job insecurity", 1 "more or less securely employed or medium level of job insecurity", 2 "insecurely employed or high job insecurity", 3 "shortterm unemployed" and 4 "long-term unemployed".

We first compared the characteristics of the five

Table 1. Descriptive statistics of the dependent measures separately for employed and unemployed individuals

\begin{tabular}{|c|c|c|c|c|c|c|c|c|c|c|c|c|}
\hline & \multicolumn{6}{|c|}{ Employed Individuals } & \multicolumn{6}{|c|}{ Unemployed Individuals } \\
\hline & Range & $M$ & $S D$ & Skew & Kurt & $\alpha$ & Range & $M$ & $S D$ & Skew & Kurt & $\alpha$ \\
\hline Self-esteem & $3.20-6.00$ & 5.19 & 0.62 & -1.20 & 1.12 & .84 & $2.00-6.00$ & 5.01 & 0.77 & -1.43 & 2.92 & .90 \\
\hline Life satisfaction & $1.86-6.00$ & 4.77 & 0.76 & -1.06 & 0.91 & .85 & $2.14-5.71$ & 4.25 & 0.75 & -0.37 & -0.33 & .79 \\
\hline Occ. self-efficacy & $3.47-6.00$ & 4.90 & 0.51 & -0.30 & -0.37 & .85 & $3.00-5.89$ & 4.67 & 0.62 & -0.61 & -0.33 & .89 \\
\hline Affective occ. & $1.00-6.00$ & 4.59 & 1.24 & -0.89 & 0.01 & .86 & $1.00-6.00$ & 4.08 & 1.28 & -0.57 & -0.23 & .84 \\
\hline
\end{tabular}

commitment

Note. All other scale values ranged from 1 to 6 , with 6 indicating strong endorsement of the construct. Occ. $=$ occupational, Skew $=$ skewness, Kurt $=$ kurtosis. 
subsamples to identify any differences in sociodemographic variables across groups varying in employment insecurity (see Table 2 for details). There were no substantial differences between the groups regarding distribution of gender, $\chi^{2}(4)=5.89, n s$, their educational level, $F(4,325)=2.11, n s$, their vocational qualification, $\chi^{2}(4)=4.68, n s$, and their partners' employment status $\chi^{2}(4)=2.81, n s$. However, average age differed significantly, $F(4,325)=9.02, p<.001$, with the long-term unemployed being on average 10 years older than the other groups. As might be expected, we also found differences in personal income, $F(4,305)=9.31, p<.001$. Participants classified as (more or less) securely employed had a higher income, with a quarter earning more than 2,000 EUR than those (shortor long-term) unemployed, with only a small percentage $(2.5 \%)$ receiving the same amount of money.
Moreover, comparison of personality traits across the groups (see Table 2 for details) revealed a higher percentage of extraverts in the securely employed group as compared to the groups of long-term unemployed and insecurely employed, $F(4,329)=2.49, p<.01$. In contrast, for neuroticism, $F(4,329)=1.83, n s$, as well as for conscientiousness, $F(4,327)=1.45$, $n s$, no differences emerged, indicating that the subsamples are at least somewhat similar regarding the personality of the participants.

\section{Preliminary analysis and statistical procedure}

Prior to the main analyses, we examined the data on mental health and occupational commitment for missing

Table 2. Controlling groups of varying employment insecurity for differences in background characteristics and personality traits

\begin{tabular}{|c|c|c|c|c|c|}
\hline & $\begin{array}{l}\text { Securely } \\
\text { Employed }\end{array}$ & $\begin{array}{c}\text { More or less } \\
\text { securely } \\
\text { employed }\end{array}$ & $\begin{array}{l}\text { Insecurely } \\
\text { employed }\end{array}$ & $\begin{array}{l}\text { Short-term } \\
\text { unemployed }\end{array}$ & $\begin{array}{l}\text { Long-term } \\
\text { unemployed }\end{array}$ \\
\hline \multicolumn{6}{|l|}{ Gender } \\
\hline Female & $64.2 \%$ & $62.8 \%$ & $44.7 \%$ & $64.3 \%$ & $58.5 \%$ \\
\hline Male & $35.8 \%$ & $37.2 \%$ & $55.3 \%$ & $35.7 \%$ & $41.5 \%$ \\
\hline Age & $\begin{array}{c}M=32.13 \\
(S D=9.81)\end{array}$ & $\begin{array}{c}M=33.72 \\
(S D=10.79)\end{array}$ & $\begin{array}{c}M=34.54 \\
(S D=12.19)\end{array}$ & $\begin{array}{c}M=36.89 \\
(S D=10.76)\end{array}$ & $\begin{array}{c}M=44.30 \\
(S D=11.16)\end{array}$ \\
\hline \multicolumn{6}{|l|}{ Educational level } \\
\hline Lower secondary & $5.9 \%$ & $5.1 \%$ & $2.1 \%$ & $1.8 \%$ & $2.5 \%$ \\
\hline Upper secondary & $17.6 \%$ & $30.1 \%$ & $40.4 \%$ & $46.4 \%$ & $35.0 \%$ \\
\hline Post-secondary & $31.4 \%$ & $41.2 \%$ & $34.0 \%$ & $17.9 \%$ & $10.0 \%$ \\
\hline First stage of tertiary education & $41.2 \%$ & $21.3 \%$ & $21.3 \%$ & $32.1 \%$ & $50.0 \%$ \\
\hline Second stage of tertiary education & $3.9 \%$ & $2.2 \%$ & $2.1 \%$ & $1.8 \%$ & $2.5 \%$ \\
\hline \multicolumn{6}{|l|}{ Vocational qualification } \\
\hline No vocational qualification & $22.6 \%$ & $14.6 \%$ & $25.5 \%$ & $25.5 \%$ & $19.5 \%$ \\
\hline Vocational qualification & $77.4 \%$ & $85.4 \%$ & $74.5 \%$ & $74.5 \%$ & $80.5 \%$ \\
\hline Personal income & $\begin{array}{c}M=1.96 \\
(S D=1.12)\end{array}$ & $\begin{array}{c}M=1.76 \\
(S D=1.28)\end{array}$ & $\begin{array}{c}M=1.39 \\
(S D=0.83)\end{array}$ & $\begin{array}{c}M=1.00 \\
(S D=0.72)\end{array}$ & $\begin{array}{c}M=0.97 \\
(S D=0.64)\end{array}$ \\
\hline \multicolumn{6}{|l|}{ Partner's employment situation } \\
\hline Partner unemployed & $22.6 \%$ & $15.0 \%$ & $17.1 \%$ & $19.1 \%$ & $22.7 \%$ \\
\hline Partner employed & $72.7 \%$ & $85.0 \%$ & $82.9 \%$ & $80.9 \%$ & $77.3 \%$ \\
\hline Neuroticism & $\begin{array}{c}M=2.26 \\
(S D=0.87)\end{array}$ & $\begin{array}{c}M=2.53 \\
(S D=0.83)\end{array}$ & $\begin{array}{c}M=2.75 \\
(S D=0.82)\end{array}$ & $\begin{array}{c}M=2.57 \\
(S D=1.18)\end{array}$ & $\begin{array}{c}M=2.58 \\
(S D=1.01)\end{array}$ \\
\hline Extraversion & $\begin{array}{c}M=4.75 \\
(S D=0.62)\end{array}$ & $\begin{array}{c}M=4.43 \\
(S D=0.71)\end{array}$ & $\begin{array}{c}M=4.21 \\
(S D=0.92)\end{array}$ & $\begin{array}{c}M=4.46 \\
(S D=0.83)\end{array}$ & $\begin{array}{c}M=4.19 \\
(S D=0.75)\end{array}$ \\
\hline Conscientiousness & $\begin{array}{c}M=4.94 \\
(S D=0.61)\end{array}$ & $\begin{array}{c}M=4.67 \\
(S D=0.59)\end{array}$ & $\begin{array}{c}M=4.77 \\
(S D=0.57)\end{array}$ & $\begin{array}{c}M=4.90 \\
(S D=0.53)\end{array}$ & $\begin{array}{c}M=4.65 \\
(S D=0.71)\end{array}$ \\
\hline
\end{tabular}

Note. Educational level was categorized according to the ISCED (OECD, 1999). The vocational qualification variable indicates whether a respondent has achieved a vocational qualification in the German dual system combining off-the-job training at vocational college with on-the-job training in a company. Personal income ranged from 0 "less than 500 EUR" to 5 "more than 4,000 EUR", and personality traits from 1 to 6 . 
Table 3. Zero-order correlations of all study variables separately for employed and unemployed individuals

\begin{tabular}{|c|c|c|c|c|c|c|c|c|c|c|c|c|c|c|c|}
\hline & & 1 & 2 & 3 & 4 & 5 & 6 & 7 & 8 & 9 & 10 & 11 & 12 & 13 & 14 \\
\hline 1 & Gender & -.02 & $-.23^{*}$ & -.08 & .04 & $-.23^{*}$ & .07 & .05 & .13 & -.08 & .03 & .12 & -.09 & -.14 & .04 \\
\hline 2 & Age & $-.23^{* * *}$ & $-.26^{* * *}$ & $.35^{* * *}$ & .09 & $.42^{* * *}$ & .10 & -.19 & -.14 & .08 & .18 & -.14 & .11 & .07 & $.23^{*}$ \\
\hline 3 & $\begin{array}{l}\text { Educational } \\
\text { level }^{\mathrm{a}}\end{array}$ & -.11 & .01 & -.02 & $-.24^{*}$ & .20 & -.14 & $-.20^{*}$ & .07 & -.00 & .10 & -.09 & .10 & -.06 & -.07 \\
\hline 4 & $\begin{array}{l}\text { Vocational } \\
\text { qualification }\end{array}$ & .00 & .09 & $-.32^{* * *}$ & -.05 & -.14 & -.01 & .10 & -.09 & .07 & -.07 & -.05 & .02 & -.13 & .13 \\
\hline 5 & $\begin{array}{l}\text { Personal } \\
\text { income }^{\mathrm{a}}\end{array}$ & $-.35^{* * *}$ & $.45^{* * *}$ & $.21^{* *}$ & .06 & $.31^{* * * *}$ & .06 & -.12 & -.04 & .05 & .17 & .02 & .14 & .17 & -.04 \\
\hline 6 & $\begin{array}{l}\text { Partner's } \\
\text { employment } \\
\text { situation }\end{array}$ & .03 & $.19^{*}$ & .08 & .10 & -.02 & .03 & -.08 & .20 & -.05 & .22 & $.28^{*}$ & .02 & -.04 & -.06 \\
\hline 7 & Neuroticism & $.15^{*}$ & -.01 & -.12 & -.01 & -.13 & -.10 & -.03 & $-.49^{* * *}$ & $-.25^{*}$ & $-.82^{* * *}$ & $-.60^{* * *}$ & $-.70^{* * *}$ & -.19 & .09 \\
\hline 8 & Extraversion & $.31^{* * *}$ & $-.14^{*}$ & -.05 & .05 & -.03 & .05 & $-.35^{* * *}$ & .07 & .11 & $.51^{* * *}$ & $.51^{* * *}$ & $.46^{* * *}$ & .11 & -.11 \\
\hline 9 & $\begin{array}{l}\text { Conscien- } \\
\text { tiousness }\end{array}$ & -.11 & .04 & .04 & $.14^{*}$ & $.22^{* *}$ & .08 & $-.25^{* * *}$ & .13 & -.03 & $.22^{*}$ & $.24^{*}$ & $.55^{* * *}$ & .18 & -.08 \\
\hline 10 & Self-esteem & .09 & -.07 & .12 & -.07 & .02 & .05 & $-.60^{* * *}$ & $.48^{* * *}$ & $.26^{* * *}$ & $.16^{* *}$ & $.74^{* * *}$ & $.60^{* * *}$ & $.26^{*}$ & -.18 \\
\hline 11 & $\begin{array}{l}\text { Life satisfac- } \\
\text { tion }\end{array}$ & .12 & -.02 & -.01 & -.04 & -.03 & .03 & $-.41^{* * *}$ & $.47^{* * *}$ & .10 & $.72^{* * *}$ & $.30^{* * *}$ & $.45^{* * *}$ & $.26^{*}$ & -.18 \\
\hline 12 & $\begin{array}{l}\text { Occ. self- } \\
\text { efficacy }\end{array}$ & $-.15^{*}$ & $.23^{* * *}$ & .03 & .05 & $.21^{* *}$ & .04 & $-.36^{* * *}$ & .08 & $.43^{* * *}$ & $.35^{* * *}$ & $.33^{* * *}$ & $.19^{* * *}$ & .09 & $-.32^{* *}$ \\
\hline 13 & $\begin{array}{l}\text { Affective occ. } \\
\text { commitment }\end{array}$ & -.04 & $.26^{* * *}$ & $.21^{* *}$ & .00 & $.24^{* * *}$ & -.02 & -.10 & .03 & $.13^{*}$ & .04 & $.18^{* *}$ & $.29^{* * *}$ & $.18^{* * *}$ & .10 \\
\hline 14 & $\begin{array}{l}\text { Length of un- } \\
\text { employment }\end{array}$ & - & - & - & - & - & - & - & - & - & - & - & 一 & 一 & - \\
\hline 15 & Job insecurity & $-.16^{*}$ & .08 & -.11 & -.01 & $-.15^{*}$ & .10 & $.17^{*}$ & $-.29^{* * *}$ & .00 & $-.26^{* * *}$ & $-.24^{* * *}$ & -.13 & $-.17^{*}$ & - \\
\hline
\end{tabular}

Note. For gender, $0=$ male; $1=$ female. Educational level was categorized according to the ISCED (OECD, 1999). For vocational qualification, $0=$ no; $1=$ yes. Personal income ranged from 0 "less than 500 EUR" to 5 "more than 4,000 EUR". For partner's employment situation, $0=$ unemployed; $1=$ employed. Participants' length of unemployment was assessed in months. All other scale values ranged from 1 to 6 , with 6 indicating strong endorsement of the construct. Occ. $=$ occupational.

Inter-correlations for employed individuals $(n=237)$ are shown below the diagonal, those for unemployed individuals $(n=97)$ above the diagonal.

${ }^{a}$ Spearman correlations. Correlations with employment status ( $0=$ being unemployed; $1=$ being employed) are shown in bold in the diagonal.

${ }^{*} p<.05,{ }^{* *} p<.01,{ }^{* * *} p<.001$.

values and assessed how well their distributions fit the assumptions of multivariate analyses. Because outliers can significantly distort the results, we inspected the sample for outliers in the dependent variables first. Six cases with extremely low $z$ scores on self-esteem and one case with an extremely low $z$ score on life satisfaction were identified as univariate outliers and deleted before performing further analyses. Kolmogorov-Smirnov $z$ tests were performed to analyze the normality of the measures employed. Whereas no deviations were found for the unemployed sample (for skewness and kurtosis see, Table 1), there were three significant deviations from normality for the sample of employed individuals: The distributions for self-esteem, life satisfaction, and affective occupational commitment were skewed towards higher scores. These findings were not unexpected, however. It is widely recognized that people tend to bias their self-assessments of mental health indicators favorably (e.g., Clark et al., 2008).

Even though the assumptions of a normal distribution were not always fulfilled, we decided to use parametric statistical tests for analyzing mean differences as “... a sample size of 30 or more is considered large enough to permit a satisfactory use or normal probabilities" (Hays,
1980, p. 318). This precondition was true for each of our five subgroups of varying employment insecurity. Moreover, as some of our socio-demographic background characteristics (gender, age, and educational level) and all three personality traits were found to correlate at the bivariate level with the dependent variables (see Table 3), we included these variables as controls. Hence, ANCOVA was chosen as an appropriate statistical procedure to test the two conflicting hypotheses. (Note, personal income was positively related to both occupational commitment indicators for the employed sample and the partner's employment status was negatively correlated with life satisfaction in the unemployed sample. However, as $29 \%$ did not have a partner, and not all were ready to report their personal income $(7.2 \%$ missing data), these two control variables could not be included in further analyses).

\section{Results}

The inter-correlations of all assessed measures, separated for the employed and unemployed individuals, are presented in Table 3. Our results replicate past research, 
Table 4. Mean comparison of mental health and occupational commitment across five groups of varying employment insecurity (ANCOVAs)

\begin{tabular}{|c|c|c|c|c|}
\hline & \multicolumn{2}{|c|}{ Mental health } & \multicolumn{2}{|c|}{ Occupational commitment } \\
\hline & $\begin{array}{l}\text { Self-esteem } \\
M(S D) \\
\end{array}$ & $\begin{array}{c}\text { Life satisfaction } \\
M(S D) \\
\end{array}$ & $\begin{array}{l}\text { Occ. self-efficacy } \\
M(S D) \\
\end{array}$ & $\begin{array}{c}\text { Affective occ. commitment } \\
\qquad M(S D) \\
\end{array}$ \\
\hline (1) Securely employed & $5.45(0.41), n=53$ & $5.01(0.55), n=53$ & $5.10(0.54), n=51$ & $4.91(1.27), n=52$ \\
\hline $\begin{array}{l}\text { (2) More of less securely } \\
\text { employed }\end{array}$ & $\begin{array}{c}5.12(0.67) \\
n=133\end{array}$ & $4.76(0.75), n=135$ & $\begin{array}{c}4.86(0.49) \\
n=134\end{array}$ & $4.56(1.18), n=133$ \\
\hline (3) Insecurely employed & $4.99(0.68), n=45$ & $4.50(0.91), n=46$ & $4.81(0.49), n=45$ & $4.31(1.33), n=46$ \\
\hline (4) Short-term unemployed & $5.11(0.82), n=52$ & $4.34(0.75), n=55$ & $4.78(0.63), n=55$ & $4.05(1.36), n=55$ \\
\hline (5) Long-term unemployed & $4.81(0.65), n=39$ & $4.17(0.69), n=39$ & $4.49(0.58), n=38$ & $4.14(1.17), n=37$ \\
\hline$F$ & $2.36^{+}$ & $7.69^{* * *}$ & $8.56^{* * *}$ & $5.62^{* * *}$ \\
\hline$d f$ & 4,304 & 4,310 & 4,305 & 4,305 \\
\hline$\eta_{p c}$ & .03 & .09 & .10 & .07 \\
\hline Group differences & $(1)>(5)$ & $(1),(2)>(4),(5)$ & $\begin{array}{l}(1)>(4),(5) \\
(2),(3)>(5)\end{array}$ & $(1),(2)>(4),(5)$ \\
\hline
\end{tabular}

Note. $N=322$ for self-esteem, $N=328$ for life satisfaction, $N=323$ for occupational self-efficacy, and $N=323$ for occupational commitment. All scale values ranged from 1 to 6 , with 6 indicating strong endorsement of the construct. Age, educational level (dummy-coded), and personality traits were included as control variables, and gender as between-subject factor. Occ. $=$ occupational. Effect sizes can be interpreted in the following way: $\eta_{p} \geq .02$ corresponds to a small effect, $\eta_{p} \geq .15$ to a medium effect, and $\eta_{p c} \geq .35$ to a large effect. Differences between the groups are shown in the last line; $p<.05$.

${ }^{+} p=.05 .{ }^{*} p<.05,{ }^{* * *} p<.001$ (two-tailed tests).

as illustrated in the diagonal, in that unemployed people report lower levels of mental health and possess lower occupational commitment, exhibited by lower self-esteem and less life satisfaction, lower occupational self-efficacy, and lower affective occupational commitment.

In our first hypothesis, we predicted that insecurely employed individuals and unemployed individuals would not differ with respect to their mental health and their occupational commitment. In contrast to that in the second hypothesis, we predicted that with increasing employment insecurity, mental health and occupational commitment would decrease. To evaluate which of these conflicting hypotheses i.e., the equal threat hypothesis or the downward spiral hypothesis holds true, ANCOVAs with the five-level group factor (securely employed to long-term unemployed) and the two-level gender factor as between-subjects factors, and age, educational level (which was dummy-coded prior to the analyses), and personality traits as controls were performed for each of the four outcomes separately: self-esteem, life satisfaction, occupational self-efficacy, and affective occupational commitment. The results of the group comparisons are depicted in Table 4. As shown for all four outcomes, a significant main effect for group was revealed.

Post-hoc comparisons with Bonferroni corrections indicated that in line with the equal threat model, those individuals who were insecurely employed did not systematically differ in terms of their mental health and their affective occupational commitment from those who were unemployed. These results fully confirm H1a, $\mathrm{H} 1 \mathrm{~b}$, and H1d, and in that contradict $\mathrm{H} 2 \mathrm{a}, \mathrm{H} 2 \mathrm{~b}$ and $\mathrm{H} 2 \mathrm{~d}$. Furthermore, for occupational self-efficacy no differences were found between insecurely employed and short-term unemployed, yet insecurely employed reported higher self-efficacy than long-term unemployed indicating that H1c has to be rejected.

With respect to occupational self-efficacy the securely employed differed from both unemployed groups, and the (more or less) insecure employed differed from the long-term unemployed only, which provides at least partial support for $\mathrm{H} 2 \mathrm{c}$, and therefore, the assumption of a downward spiral. Besides, the (more or less) securely employed participants reported better mental health than the (long-term) unemployed participants. Regarding affective occupational commitment, both unemployed groups were significantly less committed than the (more or less) securely employed.

With respect to socio-demographic control variables, women reported a stronger self-esteem than men, $F(1$, $304)=5.53, p<.05, \eta_{p c}=.02$. Furthermore, with respect to age, the older the participants, the more occupational selfefficacy, $F(1,305)=14.70, p<.001, \eta_{\mathrm{p} c}=.05$, and affective occupational commitment, $F(1,305)=14.08, \quad p<.01$, $\eta_{\mathrm{p}}=.03$, they reported. Regarding personality traits, neuroticism was negatively associated with self-esteem, $F(1,304)=159.10, \quad p<.001, \quad \eta_{\mathrm{p} c}=.34$, life satisfaction, $F(1,310)=35.93, p<.001, \eta_{\mathrm{p} c}=.10$, and occupational selfefficacy, $F(1,305)=55.28, p<.001, \eta_{p c}=.15$. In contrast to that, extraversion correlated positive with self-esteem, $F(1,304)=15.83, p<.001, \eta_{\mathrm{p} c}=.05$, and life satisfaction, $F(1,310)=34.70, p<.001, \eta_{\mathrm{p} c}=.10$, and conscientiousness with self-esteem, $F(1,304)=3.94, p<.05, \eta_{\mathrm{pc}}=.01$, and occupational self-efficacy, $F(1,305)=55.12, \quad p<.001$, $\eta_{\mathrm{p}}=.15$. Affective occupational commitment was the only dependent variable that varied independent of personality. 


\section{Discussion}

Our study aimed to shedding new light on the question of whether or not job insecurity is a similar evil to unemployment when it comes to explaining mental health and occupational commitment. To answer this question, we compared the predictive power of two conflicting hypotheses, namely the equal threat assumption and the downward spiral assumption. Based on COR theory (Hobfoll, 1989; Hobfoll \& Shirom, 2001), mental health is negatively affected if individuals are either threatened by a loss of resources or if they actually lose resources. Accordingly, the equal threat model assumes that both insecure employment and unemployment have the same negative consequences. On the other hand, the latent deprivation model (Jahoda, 1997) postulates that work serves manifest and latent functions (e.g., providing social support, structuring daily activities) which cannot be fulfilled if people are unemployed, leading Jahoda (1997) to assume that any job is better than none. This statement contradicts the equal threat model. While the threat of latent deprivation may rise the higher the employment insecurity, the downward spiral model hypothesizes that with every step downwards on the employment insecurity continuum mental health (in our study reflected by selfesteem and life satisfaction) and occupational commitment (as indicated here by occupational self-efficacy and affective occupational commitment) decrease.

Overall, our findings were more in line with the equal threat assumption, which was true for three of our four investigated outcome variables. Insecurely employed, short-term, and long-term unemployed individuals did not differ with respect to self-esteem, life satisfaction, and affective occupational commitment. Here, we observed that individuals in "bad jobs" i.e., individuals feeling insecurely employed, were not better off than unemployed individuals. The pattern of results we found supports prior research that unemployment and job insecurity can both be seen as equally threatening to mental health (e.g., Broom et al., 2006; Butterworth et al., 2011; De Witte, 1999; Dekker \& Schaufeli, 1995). Hence, as proposed by COR theory, the distress associated with the anticipation of redundancy (threat of losing the resource) appears to be comparable to that associated with the experience of unemployment itself (actual loss of the resource).

With respect to mean differences, we were only able to demonstrate that self-esteem was higher among the securely employed as compared with the long-term unemployed. This might be due to the fact that self-esteem is a rather stable construct. Epstein (1979) argues that selfesteem is based on general and higher order postulates that are not related to the experience of specific situations. Thus, self-esteem is not immediately altered by negative events. The well-established self-serving bias in healthy individuals can be seen as a confirmation of this model. Thus, we speculate that self-esteem only changes after a longer duration of unemployment - in our study, for those who were without a (paid) job for more than one year.
Next, regarding life satisfaction, we found that the unemployed reported lower satisfaction than the (more or less) securely employed. This finding is comparable to a recent study by Grün, Hauser, and Rhein (2010) showing that the lack of latent functions of work impairs life satisfaction. The same difference was revealed for affective occupational commitment. Taken collectively, the long-term and short-term unemployed were less satisfied with their lives and reported having lower affective occupational commitment than the (more or less) securely employed. One can speculate that lessening commitment to a learned or practiced occupation can be seen as a problem-focused way of coping, as it might well increase occupational mobility (Otto et al., 2010), leading unemployed people to search for jobs in other fields and thereby overcoming unemployment more efficiently. Whereas a decrease in affective occupational commitment might have at least some potential advantages however, a drop in life satisfaction definitely does not. Our findings replicate prior research indicating that unemployment decreases life satisfaction (Grün et al., 2010; Lucas et al., 2004, McKee-Ryan et al., 2005). A decline in mental health, in turn, can be seen as a threat to job searching behaviour, as it makes the process of "surviving" the job interview more difficult (see Vinokur \& Schul 2002).

Finally, in respect of the fourth outcome variable, occupational self-efficacy, mean comparisons revealed that the securely employed differed from the unemployed, whereas the more or less securely employed and the insecurely employed differed from the longterm unemployed only. This finding provides at least preliminary support for the assumption of a downward spiral. With every step downwards on the employment insecurity continuum, and therefore with the increasing threat of losing the valued latent functions of work (Jahoda, 1997), occupational self-efficacy decreases. Gzrywacz and Dooley (2003) also showed in their study differences depending on employment status which varied from optimal employment to unemployment. Moreover, our results indicate that the risk of losing faith in one's occupational self-efficacy might still increase with duration of unemployment. As Jackson (1999) pointed out, unemployed individuals have fewer opportunities to use their skills than employed individuals. In today's working world, these skills not only contain expert knowledge but also the abilities to work in teams, solve conflicts, think flexibly, etc. Being unable to use and advance one's skills regularly could possibly lead to a diminished occupational self-efficacy. This argumentation is in line with the "disuse hypothesis" (e.g., Berkowitz \& Green, 1965), suggesting that competencies which cannot be practiced diminish over time leading, for example, to the downgrading of job seekers. Thus, we argue that a decrease in occupational self-efficacy is associated with a decrease in the chances for re-employment in the labor market. The danger lies in the loss of faith in one's ability to cope with occupational demands and problems. 


\section{Shortcomings and directions for future research}

Our study has several shortcomings. First, our study is cross-sectional in nature, meaning that no causal conclusions can be drawn. Thus, impaired mental health and undermined occupational commitment may increase the likelihood of unemployment and the perception of job insecurity. In our study, mental health and occupational commitment were assessed after participants had become unemployed. Hence, it is impossible to rule out the possibility that a weak mental health or a weak occupational commitment caused unemployment, and that employees weak in those factors are at particular risk for dismissal. This point is a critical one, as metaanalytic data (Paul \& Moser, 2006) and large-scale longrun panel data of over 130,000 person-year observations in twenty waves (Clark et al., 2008) show both effects: selection into unemployment because of a bad mental health status, as well as a worsened mental health status as an effect of unemployment (socialization effect). Further longitudinal studies are thus needed to learn more about the meaning of occupational commitment in this process. In particular, assessing occupational self-efficacy and affective occupational commitment of a group of employees before some of them are confronted with job insecurity and/or made redundant might reveal whether such characteristics do indeed impact on the probability of being made unemployed.

Second, we measured job insecurity with only one item, as has been successfully done in former investigations (e.g., De Witte, 1999; Mohr, 2000). While we only used this item to categorize the employed people along the employment insecurity continuum, this nevertheless raises concerns about its reliability. The fact that this measure correlated with our outcomes in a manner consistent with our expectations (see Table 3), in spite of the attenuating effect of unreliability, should increase confidence in the meaningfulness of these findings.

Finally, all data were obtained from self-reports meaning that the effects of shared method variance may have inflated the relationships reported. In future studies, objective indicators of job insecurity, such as the duration of employment contracts, could be considered. The use of this objective criterion would allow for the comparison between employees with permanent employment contracts and those with temporary employment contracts, for whom the actual risk of losing their job and thus their perception of job insecurity is necessarily higher (Saloniemi \& Zeytinoglu, 2007).

Taking the evidence collectively, our study showed overwhelming support for the equal threat model and less for the downward spiral assumption. Yet, with self-esteem, life satisfaction, occupational self-efficacy, and affective occupational commitment, we investigated four specific and positive outcomes only. With respect to health, for example, other (negative) indicators such as emotional exhaustion, psychosomatic complaints, or depressive symptoms could also be considered in further research when comparing the predictive power of the equal threat and downward spiral models with each other.

\section{References}

Bandura, A. (1997). Self-efficacy: The exercise of control. New York, NY, USA: W. H. Freeman and Company.

Bender, S., Konietzka, D., \& Sopp, P. (2000). Diskontinuität im Erwerbsverlauf und betrieblicher Kontext [Discontinuity in the course of employment and operational context]. Kölner Zeitschrift für Soziologie und Sozialpsychologie, 52, 475-499.

Berkowitz, B., \& Green, R. E. (1965). Changes in intellect with age: V. Differential changes as functions of time interval and original score. Journal of Genetic Psychology, 53, 179-192.

Broom, D. H., D’Souza, R. M., Strazdins, L., Butterworth, P., Parslow, R., \& Rodgers, B. (2006). The lesser evil: Bad jobs or unemployment? A survey of mid-aged Australians. Social Science \& Medicine, 63, 575-586. doi: 10.1016/j.socscimed.2006.02.003

Butterworth, P., Leach, L. S., Strazdins, L., Olesen, S. C., Rodgers, B., \& Broom D. H. (2011). The psychosocial quality of work determines whether employment has benefits for mental health: Results from a longitudinal national household panel survey. Occupational and Environmental Medicine, 68, 806-812. doi: 10.1136/oem.2010.059030

Clark, A. E., Diener, E., Georgellis, Y., \& Lucas, R. E. (2008). Lags and leads in life satisfaction: A test of the baseline hypothesis. The Economic Journal, 118, 222-243.

Costa, P. T., \& McCrae, R. R. (1989). NEO-PI/FFI Manual Supplement. Odessa, FL, USA: Psychological Assessment Resources.

Creed, P. A., Muller, J., \& Machin, M. A. (2001). The role of satisfaction with occupational status, neuroticism, financial strain and categories of experience in predicting mental health in the unemployed. Personality and Individual Differences, 30, 435-447. doi: 10.1016/S0191-8869(00)00035-0

Dalbert, C. (1992). Subjektives Wohlbefinden junger Erwachsener: Theoretische und empirische Analysen der Struktur und Stabilität [Subjective well-being of young adults: Theoretical and empirical analyses of the structure and stability]. Zeitschrift für Differentielle und Diagnostische Psychologie, 13, 207-220.

De Witte, H. (1999). Job insecurity and psychological well-being: Review of the literature and exploration of some unresolved issues. European Journal of Work and Organizational Psychology, 8, 155-177. doi: 10.1080/135943299398302

Dekker, S., \& Schaufeli, W. (1995). The effects of job insecurity on psychological health and withdrawal: a longitudinal study. Australian Psychologist, 30, 5763. doi: 10.1080/00050069508259607 
DeNeve, K. M., \& Cooper, H. (1998). The happy personality: A meta-analysis of 137 personality traits and subjective well-being. Psychological Bulletin, 124, 197-229. doi: 10.1037/0033-2909.124.2.197

Deusinger, I. M. (1986). Die Frankfurter Selbstkonzeptskalen [The Frankfurt Self-Concept Scales]. Göttingen, Germany: Hogrefe.

Dzuka, J., \& Dalbert, C. (2002). Mental health and personality of Slovak unemployed adolescents: The impact of belief in a just world. Journal of Applied Social Psychology, 32, 732-757. doi: 10.1111/j.15591816.2002.tb00240.x

Epstein, S. (1979). Entwurf einer Integrativen Persönlichkeitstheorie [Design an integrative personality theory]. In S. H. Filipp(Ed.), SelbstkonzeptForschung [Self-concept research] (pp. 15-46). Stuttgart, Germany: Klett.

Elovainio, M., Kivimäki, M., Kortteinen, M., \& Tuomikoski, H. (2001). Socioeconomic status, hostility and health. Personality and Individual Differences, 31, 303-315. doi: 10.1016/S0191-8869(00)00137-9

Eurobarometer (2012). Standard Eurobarometer 78: Public opinion in the European Union. Retrieved from http://ec.europa.eu/public opinion/index en.htm

Grobe, T. (2006). Sterben Arbeitslose früher [Are the unemployed dying earlier]? In A. Hollederer, \& H. Brand (Eds.), Arbeitslosigkeit, Gesundheit und Krankheit [Unemployment, health and disease] (pp. 75-83). Bern, Switzerland: Huber.

Grün, C., Hauser, W., \& Rhein, T. (2010). Is any job better than no job? Life satisfaction and re-employment. Journal of Labour Research, 31, 285-306. doi: 10.1007/s12122-010-9093-2

Grzywacz, J. G., \& Dooley, D. (2003). "Good jobs" to "bad jobs": Replicated evidence of an employment continuum from two large surveys. Social Science \& Medicine, 56, 1749-1760. doi: 10.1016/S0277-9536(02)00170-3

Hays, W. L. (1980). Statistics for the social sciences. London, United Kingdom: Holt.

Hobfoll, S. E. (1989). Conservation of resources: A new attempt at conceptualizing stress. American Psychologist, 44, 513-524.

Hobfoll, S. E., \& Shirom. A. (2001). Conservation of resources theory: Applications to stress and management in the workplace. In R. T. Golembiewski (Ed.), Handbook of Organizational Behavior (pp. 57-80). New York, NY, USA: Dekker.

Jackson, T. (1999). Differences in psychosocial experiences of employed, unemployed, and student samples of young adults. The Journal of Psychology, 133, 49-60. doi: 10.1080/00223989909599721

Jahoda, M. (1997). Manifest and latent functions. In N. Nicholson (Ed.), The Blackwell encyclopedic dictionary of organizational psychology (pp. 317318). Oxford, United Kingdom: Blackwell.

Judge, T. A. (2009). Core self-evaluations and work success. Current Directions in Psychological Science, 18, 58-62. doi: 10.1111/j.1467-8721.2009.01606.x
Keddy, B., Cable, B., Quinn, S., \& Melanson, J. (1993). Interrupted work histories: Retired women telling their stories. Health Care for Women International, 14, 437-446.

Kieselbach, T. (2003). Long-term unemployment among young people: The risk of social exclusion. American Journal of Community Psychology, 32, 69-76. doi: 10.1023/A:1025694823396

Kinnunen, U., Feldt, T., \& Mauno, S. (2003). Job insecurity and self-esteem: Evidence from crosslagged relations in a 1-year longitudinal sample. Personality and Individual Differences, 35, 617-632. doi: 10.1016/S0191-8869(02)00223-4

Kulik, L. (2001). Assessing job search intensity and unemployment-related attitudes among young adults: Intergenderdifferences. JournalofCareer Assessment, 9, 153-167. doi: 10.1177/106907270100900204

Lee, K., Carswell, J. J., \& Allen, N. J. (2000). A metaanalytic review of occupational commitment: Relations with person- and work-related variables. Journal of Applied Psychology, 85, 799-811. doi: 10.1037/0021-9010.85.5.799

Letkemann, P. (2002). Unemployed professionals, stigma management, and derivative stigmata. Work, Employment \& Society, 16, 511-522. doi: 10.1177/095001702762217461

Lucas, R. E., Clark, A. E., Georgellis, Y., \& Diener, E. (2004). Unemployment alters the set point for life satisfaction. Psychological Science, 15, 8-13.

Lucas, R. E., Diener, E., \& Suh, E. (1996). Discriminant validity of well-being measures. Journal of Personality and Social Psychology, 71, 616-628. doi: 10.1037/0022-3514.71.3.616

Mantler, J., Matejicek, A., Matheson, K, \& Anisman, H. (2005). Coping with employment uncertainty: A Comparison of employed and unemployed workers. Journal of Occupational Health Psychology, 10, 200-209. doi: 10.1037/1076-8998.10.3.200

Mark, A. S., \& Mueller, J. (2000). Job insecurity, coping resources and personality dispositions in occupational strain. Work \& Stress, 14, 312-328. doi: 10.1080/02678370010022462

Mauno, S., Feldt, T., Tolvanen, A., Hyvönen, K., \& Kinnunen,U.(2011). Prospectiverelationships between career disruptions and subjective well-being: Evidence from a three-wave follow-up study. International Archives of Occupational Environmental Health, 84, 501-512. doi: 10.1007/s00420-010-0583-6

McKee-Ryan, F. M., Song, Z., Wanberg, C. R., \& Kinicki, A. J. (2005). Psychological and physical well-being during unemployment. A meta-analytic study. Journal of Applied Psychology, 90, 53-76. doi: 10.1037/0021-9010.90.1.53

Meyer, J. P., Allen, N. J., \& Smith, C.A. (1993). Commitment to organizations: Extension and test of a three-component conceptualization. Journal of Applied Psychology, 78, 538-551. doi: 10.1037/0021-9010.78.4.538 
Mohr, G. (2000). The changing significance of different stressors after the announcement of bankrupty: A longitudinal investigation with special emphasis on job insecurity. Journal of Organizational Behavior, 21, 337-359. doi: 10.1002/(SICI)10991379(200005)21:3<337::AID-JOB18>3.0.CO;2-G

Mohr, G., \& Otto, K. (2011). Health effects of unemployment and job insecurity. In A. S. Antoniou, \& C. Cooper (Eds.), New directions in organizational psychology and behavioral medicine (pp. 289-311). Gower Publishing, United Kingdom: Surrey.

Neuberger, O., \& Allerbeck, M. (1978). Messung und Analyse von Arbeitszufriedenheit [Measurement and analysis of job satisfaction]. Bern, Switzerland: Huber.

Oberholzer-Gee, F. (2008). Nonemployment stigma as rational herding: A field experiment. Journal of Economic Behavior \& Organization, 65, 30-40. doi: 10.1016/j.jebo.2004.05.008

Otto, K., \& Dalbert, C. (2012). Individual differences in job-related relocation readiness: The impact of personality dispositions and social orientations. Career Development International, 17, 168-186. doi: 10.1108/13620431211225340

Otto, K., Dette-Hagenmeyer, D. E., \& Dalbert, C. (2010). Occupational mobility in members of the labor force: Explaining the willingness to change occupations. Journal of Career Development, 36, 262-288. doi: 10.1177/0894845309345842

Otto, K., Hoffmann-Biencourt, A., \& Mohr, G. (2011). Is there a buffering effect of flexibility for job attitudes and work-related strain under conditions of high job insecurity and regional unemployment rate? Economic and Industrial Democracy, 32, 609-630. doi: $10.1177 / 0143831 \mathrm{X} 10388531$

Paul, K. I., Geithner, E., \& Moser, K. (2009). Latent deprivation among people who are employed, unemployed, or out of the labor force. The Journal of Psychology, 143, 477-491.

Paul, K., \& Moser, K. (2006). Quantitative reviews in psychological unemployment research: An overview. In T. Kieselbach, A. Winefield, C. Byod, \& S. Anderson (Eds.), Unemployment and health (pp. 5159). Brisbane, Australia: Australian Academic Press.

Paul, K. I., \& Moser, K. (2009). Unemployment impairs mental health: Meta-analyses. Journal of Vocational Behavior, 74, 264-282. doi: 10.1016/j.jvb.2009.01.001

Rigotti, T., Schyns, B., \& Mohr, G. (2008). A short version of the occupational self-efficacy scale: Structural and construct validity across five countries. Journal of Career Assessment, 16, 238-255. doi: 10.1177/1069072707305763

Rosenberg, M., Schoenbach, C., Schooler, C., \& Rosenberg, F. (1995). Global self-esteem and specific self-esteem: Different concepts, different outcomes. American Sociological Review, 60, 141-156.

Rosenblatt, Z., \& Ruvio, A. (1996). A test of a multidimensional model of job insecurity: The case of Israeli teachers. Journal of Organizational Behavior, 17, 587-605. doi: 10.1002/(SICI)10991379(199612)17:1+<587::AID-JOB825>3.0.CO;2-S

Saloniemi, A., \& Zeytinoglu, I. U. (2007). Achieving flexibility through insecurity: A comparison of work environments in fixed-term and permanent jobs in Finland and Canada. European Journal of Industrial Relations, 13, 109-128. doi: 10.1177/0959680107073971

Schwarz, P. (2012). Neighborhood effects of high unemployment rates: Welfare implications among different social groups. The Journal of SocioEconomics, 41, 180-188.

Schyns, B., \& von Collani, G. (2002). A new occupational self-efficacy scale and its relation to personality constructs and organizational variables. European Journal of Work and Organizational Psychology, 11, 219-241. doi: 10.1080/13594320244000148

Soldz, S., \& Vaillant, G. E. (1999). The Big Five personality traits and the life course: A 45-year longitudinal study. Journal of Research in Personality, 33, 208-232. doi: 10.1006/jrpe.1999.2243

Spector, P. E., \& Brannick, M. T. (2011). Methodological urban legends: The misuse of statistical control variables. Organizational Research Methods, 14, 287-305.

Sverke, M., Hellgren, J., \& Näswall, K. (2002). No security: A meta-analysis and review of job insecurity and its consequences. Journal of Occupational Health Psychology, 7, 242-264. doi: 10.1037/1076-8998.7.3.242

Trautwein, U., Köller, O., Watermann, R., Lüdtke, O., Maaz, K., Nagy, G., \& Baumert, J. (2000). Bildungsverläufe und psychosoziale Entwicklung im Jugend- und jungen Erwachsenenalter (BIJU): Längsschnitt 1: Dokumentation der 6. Datenerhebung [Educational pathways and psychosocial development in youth and young adulthood (BIJU): longitudinal section 1: Documentation of 6th data collection]. Berlin, Germany: Max-Planck-Institut fürBildungsforschung, Unpublished Scale.

Vinokur, A. D., \& Schul, Y. (2002). The Web of coping resources and pathways to reemployment following a job loss. Journal of Occupational Health Psychology, 7, 68-83. 